International Journal of Linguistics, Literature and Culture
Available online at https://sloap.org/journals/index.php/ijllc/
Vol. 4, No. 6, November 2018, pages: $17 \sim 27$
ISSN: $2455-8028$
https://sloap.org/journals/index.php/ijllc/article/view/335

\title{
Structure and Culture Values of Sasak Story: Story of King Kuripan and Its Relevation with Language and Literature Learning
}

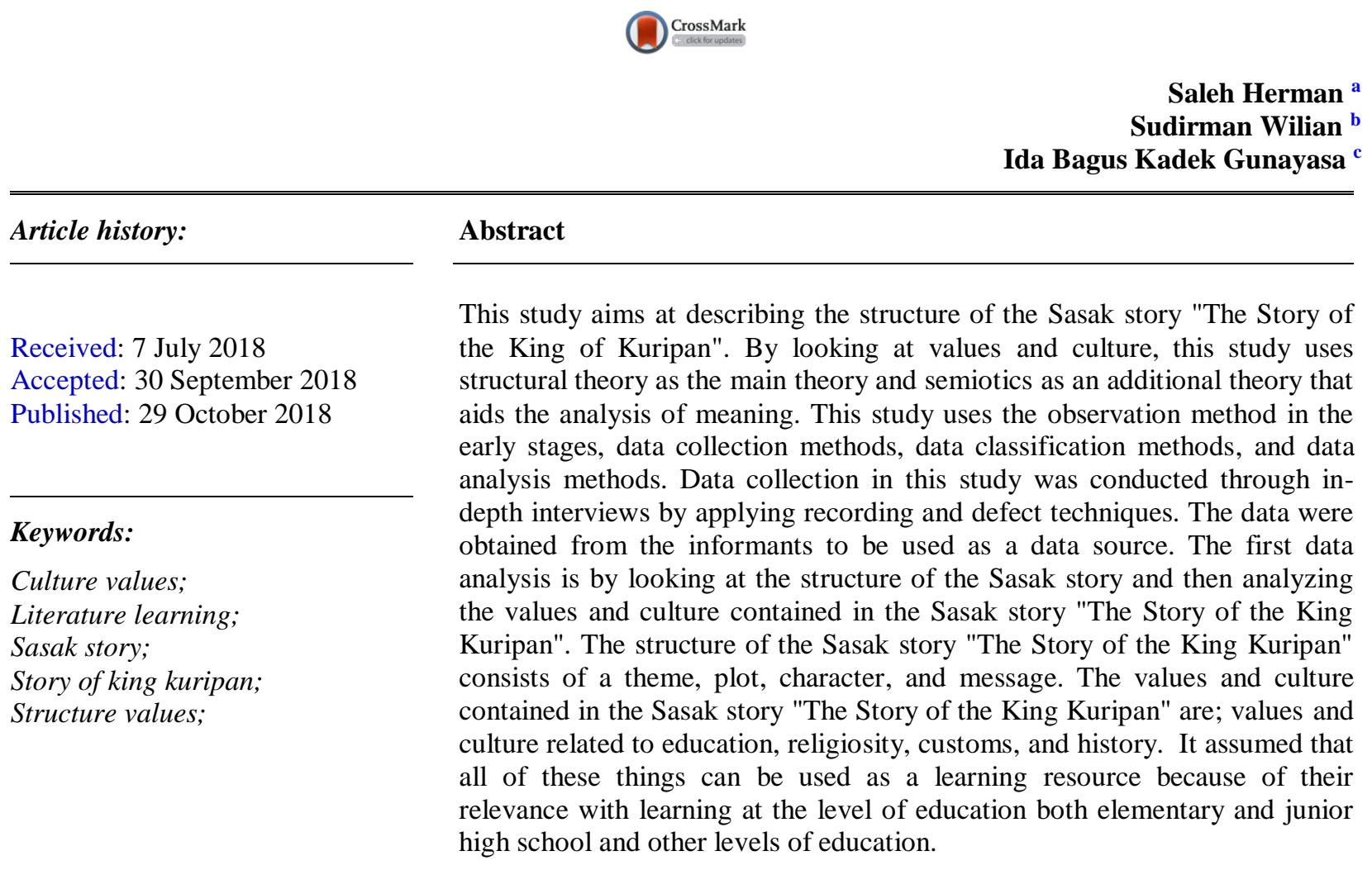

2455-8028 ${ }^{\circledR}$ Copyright 2018. The Author. This is an open-access article under the CC BY-SA license (https://creativecommons.org/licenses/by-sa/4.0/) All rights reserved.

\section{Author correspondence:}

Saleh Herman,

Mataram University, Indonesia

Email address: salehherman74@gmail.com

\section{Introduction}

\footnotetext{
${ }^{a}$ Mataram University, Indonesia

${ }^{\mathrm{b}}$ Mataram University, Indonesia

${ }^{\mathrm{c}}$ Mataram University, Indonesia
} 
Work of literature is one of the artworks containing elements of beauty that can cause feelings of pleasure, luxury, compassion, attention, and refreshing for the audience. In this case, Kuripan is one of the names pinned to a village that is quite well known in West Lombok. The story of kings in the past such as the story of king Kuripan in West Lombok has obtained a special place in the Kuripan community today. The story that was attached to the past also got its own place for the continuation of the new generations and became an integral part of people's lives, as the owner of the culture includes the activities of literature.

Literary work can be divided into oral and written. Oral literature is the result of regional literary works expressed through the activities of storytelling. In oral literature/Sasak stories "The Story of the King Kuripan", the socio-cultural situation of the Sasak people is expressed containing a description of the social, cultural and public belief systems. In addition, it also contains a description of the nobility (prominent noble), poor, and rich, the professional community, and other social problems.

The Sasak story "The Story of the King Kuripan" is a folklore that was once strengthened in the community spread from mouth to mouth, but its existence is now fading. In addition, to the limitations of human memory in remembering, increasingly sophisticated technological developments globalized are also now shifting oral literature that ever existed, including Kuripan community oral literature. However, what makes the writer interested in researching it is the existence of Kuripan Name so that it can be said that there is no effect without a cause. What is seen today is one of the real evidence in the community. As a cultural product of the community, almost all regions in Indonesia have oral literature, both prose, and poetry genres but today the existence of oral literature begins warns us caused by the ignorance of the community towards oral literature. Oral literature which is only seen as a story that does not make sense and is not within the reach of morality. That, of course, is a threat to the existence of oral literature in people's lives.

From a cultural perspective, the development of society today has deteriorated. The weakness of the current cultural defenses precisely causes the Indonesian society to be overcrowded so that it cannot distinguish which cultures should be held in accordance with the characteristics of the eastern community and which cultures need to be digested. With this condition, it can be witnessed the economic downturn, political turmoil, social tensions and rifts that emerge deviant behaviors, such as corruption, student brawls, excessive emancipation of women, even today the Indonesian people are preoccupied with the rampant acts of terrorism and various other problems that should be eliminated as a society with a noble culture.

Folklores were initially conveyed through speech media by someone in the group to members of the group. Then it just becomes a story just off without any important documents that are recorded until the story can become a history that contains valuable lessons for the next generation.

Parents advise their family members or shamans in the village to tell stories about myths, legends, or tales for specific purposes. In general, folklore is conveyed when advising and providing learning about a thing, moral values and all the rules applied in the community or to entertain community member.

Today folklore can be heard only from the elderly parents. Basically, the folklore has similarities in folklore patterns of other cultures in Indonesia, namely: the occurrence of the universe (cosmogony); the formation of the gods; world of gods (pantheon); the occurrence of the first human and cultural bearer (cultural hero); the occurrence of staple foods such as rice and so on, for the first time. Many oral stories, which were once believed even today are still guidelines for the Sasak tribe. Almost all of Sasak's stories depict collateral and vertical relations between humans in everyday social life. The stories and legends are power relations between kings and ordinary people, as well as cooperative relations between ordinary people.

Researchers' interest in raising the Sasak story "The Story of the King Kuripan" is driven by the fact that this story has a noble cultural value which is in accordance with the characteristics of the Sasak community, therefore, this literary work needs to be maintained and explained to our future generations through formal education or nonformal. This is in line with the aim of our national education namely to construct a whole Indonesian human being. Thus, the results of this study are expected to contribute to the development of character education. Considering the values contained in the Sasak story "The Story of the King Kuripan", it is necessary to do a comprehensive research effort so that the story is not extinct because this oral story is very vulnerable to its incompetence in the life of society today, which is caused by several factors, between another is a shift in the increasingly globalized pattern of people's lives where humans are always pursuing and fulfilling their daily needs so that there is no time to pay attention to the cultural norms prevailing in society. This should not be allowed to go on for too long by the community, the people of Kuripan know about the oral story. Based upon this, it has never been heard again. Since oral literature is increasingly fading and only based on the memory of the speaker it can change the authenticity of an 
oral literature, the researcher feels interested in studying it and documenting it. The main goal to be achieved in this research is that it can make oral literature a literary that is always alive and can be maintained.

Thus, the problems raised in this study are: (a) what is the structure of the Sasak story "The Story of the King Kuripan?"; (b) how is the cultural value contained in the Sasak story "The Story of the King Kuripan?"; (c) what is the relevance between the results of the Sasak story study "The Story of the King Kuripan" with literary learning in SMPN?, while the objectives to be achieved: (a) describing the story structure of Sasak "The Story of the King Kuripan"; (b) studying the cultural values contained in the Sasak story "The Story of the King Kuripan"; (c) Analyzing the relevance between the results of the Sasak story research "The Story of the King Kuripan" with literary learning at SMPN.

As it used descriptive qualitative research design, the data were collected by recording techniques, interviews, and literature and analyzed using Semiotic Structural theory while for the development in learning, it used constructivism theory. The results of this study are expected to be useful both theoretically and practically.

\section{Materials and Methods}

This research is a field research with descriptive qualitative research design with data sources derived from each utterance that has been transcribed into the written language (Moleong, 2011). In connection with this, the data collection method used is a participatory observation method combined with recording techniques and unstructured interview techniques with the intralingual matching method as a method of analyzing data, which is accompanied by informal and formal methods as a method of presenting the data.

\section{Theoretical Framework}

According to Vansina's (1985: 68) viewed structure is defined as each message containing a structure. It is in line with Preminger et al., (1974: 286) (in Teeuw, 1994) discussing various opinions about structure. The most common term is a meter, while a structure is defined as a style. Next, W.P. Ker describes the structure as an argument. In addition, the structure is also defined as a genre (from Plato). In this case, the structure is not just an argument or as a genre, but as a real combination of elements.

This structural theory is one of the main theories used as the basis for this study. According to structural theory, a literary work is a structure. The structure consists of components that are functionally related to each other so that a complete meaning is constructed.

A. Teeuw (1984:135) states that principally, the theory of structural aims at studying, revealing and describing as closely as possible the linkages and interwoven existing between elements that together produce whole meaning. In connection with this, what is important in structural theory is the relationship between elements that build logical relationships. The most prominent feature of the structure is its attention to wholeness and totality. Structural people believe that totality is more important than its part. In relation to structure, Hamzah (1985: 96 (in Faruk, 1999) says that scenario structure is contained in elements of plot, character, and theme. These three elements constitute an inseparable unity. The line is the structure of creation, a series of events, and actions. The character will be found in the character who will carry out the plot. The reaction of the character will cause an event or problem -problem. The problem is called a theme.

The next opinion by Piaget (1995: 4-9) (in Nugiantoro, 2002) says that the structure has three characteristics, namely (1) Totality, meaning that the elements in the structure must be related to one another to become a single entity, (2) transformation meaning that the elements in the structure become compilers and arranged at once, and (3) self-regulation meaning that the elements that build the structure can regulate themselves so that they become protected and closed.

Structural analysis of Sasak folklore "The Story of the King Kuripan" in this case can be done by identifying, examining, and describing the physical intrinsic functions and its relationships. Thus, basically, structural analysis aims to explain as carefully as possible the functions and interrelations between various elements of literary work that together produce a unity. Structural analysis cannot merely be done by recording certain elements of Sasak folklore "The Story of the King Kuripan", for example, events, plots, settings, or anything else. But more important is to show how the relationship between elements, and what contribution is given to the aesthetic goals and the overall meaning to be achieved.

Herman, S., Wilian, S., \& Gunayasa, I. B. K. (2018). Structure and culture values of sasak story: story of king kuripan and its relevation with language and literature learning. International Journal of Linguistics, Literature and Culture, 4(6), 17-27. https://doi.org/10.21744/ijllc.v4n6.335 
In this case, an analysis of Sasak folklore "The Story of King Kuripan" aims at understanding the meaning of Sasak folklore "The Story of the King Kuripan". Next is meaningful. Sasak folklore "The Story of King Kuripan", as with other oral literature, is a traditional work of art which can also be called analyzing Sasak folklore "The Story of the King of Kuripan" is an attempt to capture and give meaning to Sasak folklore "The Story of the King Kuripan". Sasak folklore "The Story of King Kuripan" is a structure of linguistic art (Abdullah, 1991: 6). Sasak folklore stories "The Story of King Kuripan" is a sign system that has meaning using language as its medium.

Language in Sasak folklore "The Story of the King Kuripan" has a different position to use in ordinary communication, even it is directed at things or things designated in the external world (practical functions), besides on the sign itself (poetic function). Therefore, linguistic art texts in principle draw attention to the structure of signs that indirectly or figuratively provide information relevant to the social context by Saussure (in Abdullah, 1991: 6). In connection with this, Lotman said that language is the first world model system, which is fostering a world of realworld models that influence and dominate the lives of individuals and society, while literary works are a second world model system because there is already interwoven into the sign system (Teeuw, 1988: 258; Abdullah, 1991: 67).

Language as a medium of Sasak folklore "The Story of King Kuripan" is already a semiotic or signification system, namely a signification system that has meaning. Medium Sasak folklore "The Story of King Kuripan" is in the form of words (language). Therefore, before being used in Sasak folklore "The Story of the King of Kuripan" is already a symbol that has a meaning determined by the community agreement (language) or determined by the community convention. Symbols or signs of language are in the form of sound units which have meaning by the convention of society. The language is a signification system that is based on or determined by community conventions (agreements). The signification system is called semiotics or semiology.

The text of the Sasak folklore "The Story of the King of Kuripan" as a semiotic phenomenon is in a network of relationships that are quite complex and full of dynamics, in the sense of constantly changing. This dynamic relationship is multidimensional built up from a number of tensions derived from the semiotic model (Teeuw, 1984: 86-87). Tensions that move the multidimensional dynamics faced by connoisseurs, namely collective work in relation to the language system, literary system, socio-cultural system, creator intention, connoisseur competence, and tension in the system of coherence of the elements of the structure of the work itself. In addition, tension also occurs between connoisseurs as individuals and connoisseurs as members of society, between connoisseurs as present-day humans and the granting of their present meaning, and connoisseurs in the history. Facing the text of Sasak folklore "The Story of King Kuripan" as a semiotic fact, connoisseurs are in the tension between reality and imagination. In conjunction with the text of oral tradition, connoisseurs face the work in the tension between stability and variation. The tension brought about by this multidimensional dynamic towards a tradition of art creation turns out to be the basis for aesthetic satisfaction considerations for connoisseurs. The contradiction between expectations fulfilled with hopes that are disappointed might determine the high and low aesthetic values received by connoisseurs (Teeuw, 1984: 358-361).

This study is focused on the Sasak folklore "The story of The King Kuripan". The Sasak folklore "The story of The King Kuripan" is presented in Sasak language is a result of storytelling done by a member of Sasak community with the good experience of telling a story and excellent ability in doing storytelling. In this context, the theory of semiotic is utilized to analyze language form and the literature of Sasak folklore "The story of The King Kuripan". In the semiotic view, literary work is a sign system that will be meaningful if interpreted by the reader based on the conventions related to it. The literary theory that understands literature as a sign is called literary semiotics.

This Sasak folklore study "The Story of the King of Kuripan" prioritizes the sign relationship as a symbol by giving attention to language conventions, literary conventions, and cultural conventions.

The term of Constructivism itself can actually be traced in Bartlett's work (1932: 92 (in Goldman, 1977), in Mark Baldwin's and which in more detail is deepened by Jean Piaget, then Piaget's concept was disseminated in North America (covering the United States and Canada) by Ernst von Glasersfeld. However, the concept related to Constructivism (even though at that time it had not used the term Constructivism) was even revealed by Giambattista Vico in 1710, which states that the meaning of "knowing means knowing how to make things". This means that someone can be said to know something if he can explain what elements are building something or more clearly he has experienced with the thing maybe several times and there is acceptance in his cognitive structure, as a result of his process of thinking (the process of mind) about what it really is. The essence of Constructivism theory is that students must make information became officially his or her own. Brooks (in Probonogoro, 1998), sees students constantly check new information that is contrary to the rules if it is no longer appropriate. Constructivism theory requires students to play an active role in learning, the emphasis is on active students. Constructivism strategy is 
often called student-centered instruction. In this context, students find facts, concepts, or principles for themselves, even giving lectures or controlling all activities in the classroom. Meanwhile, a number of other experts have argued that Constructivism is a form of pragmatism. Therefore, it is understandable if the pragmatism figure, Jhon Dewey, who is famous for the concept of learning by doing, is categorized as an expert in constructivism.

The followers of Constructivism underlie their thinking that knowledge is not a given thing from nature because of the result of human contact (formed) of human being itself. Knowledge is not an imitation of reality (reality). Knowledge is not a picture of the world of reality. Knowledge is always the result of a cognitive construction reality through one's activities. It forms the schemes, categories, concepts, and structures of knowledge needed for the knowledge needed for knowledge (Bettencourt, 1989 in Riffaterre, 1979: 18).

Constructivism believes that learners construct their own relationships or at least translate them based on perceptions of previous experiences, as well as their mental structures which are then used to translate new objects and events. The experts involved in this flow include Bruner, Ulrick, Neiser, Kant, Dewey, and Habermas. But what plays a major role, namely the work of Jean Piaget, which was later translated and developed by Ernst von Glasersfeld. Before the development by von Glasersfeld, Piaget's work was not widely known in North America.

Meanwhile, Driver and Bell (in Ikram, 1997) propose the characteristics of Constructivism learning as follows, (i) students are not seen as passive but have goals, (ii) learning must consider as optimal as possible the process of student involvement, (iii) knowledge is not something that comes from outside, but is constructed personally, (iv) learning is not knowledge transmission, but involves setting the situation of the learning environment, (v) the curriculum is not just a matter of learning, but a set of learning, material, and resources.

The purpose of learning is how each individual construct meaning, not just remembers the right answer and rejects the meaning of others. Because education in its nature is indeed interdisciplinary, the only convincing way to measure learning outcomes is to assess the parts of the learning process, ensuring that each student will get information about the quality of learning.

\section{Results and Discussions}

The forms of literary works found in the archipelago are very diverse and have their own identities or characteristics for each region. Even more, as Sasak community is very well known for its literary works, both written and oral, written literary works are engraved on various types and materials that are still natural, such as palm leaves, which contain the story of the various traces of the king and wise people. Whereas, it is in the oral form of historical records. Where at that time they did not know the writing tradition or known by the oral tradition that is the tradition of pouring out complaints and instilling various values and norms in the form of stories by way of verbal to writing.

The objectives of learning literature especially for language programs is Literature allows humans to be able to make themselves as human beings who are whole, independent, behave smoothly, tolerate with each other, and respect others in accordance with their dignity. Therefore, learning Indonesian literature is directed to the formation of students who are noble personalities, with literary knowledge, and be positive and appreciative of Indonesian literature. Indonesian Literature Subjects aim at making students have the following abilities: 1) to understand, and utilize literary works to develop personality, broaden the horizons of life, and improve knowledge and language skills; 2) to express himself in the medium of literature; and 3) to appreciate and boast Indonesian literature as a cultural and intellectual treasure of Indonesian people.

\section{Traditions in Sasak Community}

Tradition is a custom regarding anything carried out by a particular society that is passed down from generation to generation both orally and in writing. The Sasak (Lombok) community has several traditions and has developed since a long time ago. Some traditions have been lost (extinct), some are going to the extinction process because they are marginalized, and some are being maintained and will continue to be maintained. Traditions that still exist in the life of the Sasak people are traditions that are usually carried out together with harvest parties called bekeloq, a salvation ceremony called begawedan which is called betuturan which is carried out at all times. The following are traditions that are still routinely carried out based on traditional Sasak time (calendar). This can be noted in the section below.

Herman, S., Wilian, S., \& Gunayasa, I. B. K. (2018). Structure and culture values of sasak story: story of king kuripan and its relevation with language and literature learning. International Journal of Linguistics, Literature and Culture, 4(6), 17-27. https://doi.org/10.21744/ijllc.v4n6.335 


\section{(a) Tradition Becilokaq}

According to Mustakim Biawan Musician, Cilokaq is a typical art in Lombok. The tone is seductive which in every song that is created almost has the same feel of rhythm. For this reason, if this music is performed in a variety of different song titles, there is hardly anything new from the accompanying rhythm. "It might be monotonous because that is the art of Cilokaq, but to enrich it is good to collaborate with other performing arts," he said.

Cilokaq music has indeed been affected by the Sasak community for several decades. Several albums have been reported, one of them is " Kembang Jelantik " a music Group Selemor Ate Desa Jelantik, Jonggat District, Central Lombok, earlier. These rural songs were created by Lalu Prawira S - including " Peng'iling-iling ", " Sangsara ", " Berembe Angen ", " Anak Iwoq ", " Merariq Masih Kodeq ", " Iroq Aseq ", " Ngelai Dese ", " Buak Bile " and " Panggugah Ate ". The presence of Cilokaq music art cannot be separated from the function of entertainment in various events in Lombok such as marriage, circumcision, in addition to functioning to provide enthusiasm or entertainment to unwind. Because of its flexibility in space, this art of music can be done anywhere, both in the open space and on stage. His presence, using stringed instruments, stringing (violin), wind instruments (flutes and rows) and musical instruments (drum), became part of the diversity that enriched the colors of music in NTB.

However, the root of word Cilokaq is still in a big question mark. Some say that it comes from the word "seloka" following the various poems performed are seloka. This music group first performed in 1948 in Lengkok Kali Village, Sakra District, East Lombok led by Mamiq Srinatih (late). Songs that are performed are generally in the form of kayak with a nondiatonic tone arrangement such as the kayaq "Turun Tangis", "Pemban Selaparang", "Jeruk Manis", and others.

Kayaq is extremely popular in the Lombok community, especially with the nondiatonic tone brought by the community when planting rice. But each village has its own kayaq in accordance with the name of the village. This Kayaq consists of four rows in the form of rhymes in the form of advice with a four-tone celendal system. For example, it sounds: Bangket payaq ariq, sintung goro/Kelak kelor ariq, sintung tumpah/ Te bekayaq ariq poroqporoq/Mun selembar ariq ate susah (The rice fiel is planted by sister, anyway dry/Cook Kelor leaves, sister but spilled / Let's do kayaq, sister, to forget a heavy heart).

\section{(b) Tradition Pepaosan}

Besides, the habit of developing and reading ejection is also usually done when there is a feast party. Sometimes along with the 'beredang' event (Balinese: pegadang). Lontar is usually read in a special place called paosan. Paosan is a rectangular building with four pillars, each of which is a symbol of the four pillars of the teachings of Islam, namely: Shari'ah, Tarekat, Ma'rifat, and Shahada. Each symbol is given meaning in accordance with the teachings of Islam, therefore this building is functioned in accordance with the social life of the Sasak people with an Islamic background. This building is usually placed in the middle of the yard, arranged artistically, and is considered a respectable place for the people of Lombok. Therefore, all buildings for residential houses is built front on the paosan. Paosan placed in the middle of this page has multifunctionality, all social activities are carried out in this place, including studying religion or reading the Qur'an, reading lontar and so on. Lontar commonly read in paosan are Cilinaya, Rengganis, Kendit Birayung, Babad Sakra, Indarjaya, Puspakerma, Monyeh, and others.

Thus, the tradition of singing poetry, singing, and playing together, was initially carried out in connection with the postharvest party, then continued during the salvation ceremonies and other social activities. This atmosphere reflects the calm, safe atmosphere of the community, free time available, and fulfilling basic needs. The tradition eventually became the only entertainment that was very interesting for them and always became a routine attraction when releasing fatigue.

\section{(c) Tradition Betuaran (Stroy telling)}

The tradition of betuaran (storytelling) is owned by all ethnic groups in the archipelago. The types, forms and ways of telling are very diverse. All of that depends on the situation of the community, both related to the sociocultural background, customs, and beliefs they hold. The tradition of betuaran (storytelling) in the Sasak community have existed almost simultaneously with human existence in Lombok because it continues to be created and enjoyed by the Sasak community. Wewaran (fairy tales) have become part of the life experience of the people of Lombok because in wewaran (fairy tales) there are various kinds of good values that can be used as guidelines in living a life in society. It cannot be denied that the development of authority (fairy tales) in the Sasak community is currently experiencing ups and downs, as the progress experienced by humanity, many kinds of literature have been created, such as romance, novels, short stories, dramas, and so on. Although there was a shift in the orientation of society 
towards the creation of literature as mentioned above, the tradition of bewaran (storytelling) is still being carried out, especially by traditional communities in the village. Wewaran (fairy tale) which is famous and often raised in the betuaran (storytelling), among others, Batu Goloq, Datu Langko, Embung Putiq, Gunung Pujut, Raga Dundang, Riwayat Datu Pejanggiq, Tempiq-Empiq, and others.

Table 1

Values in learning literature as a medium of character education

\begin{tabular}{|l|l|}
\hline 1. Religious & 10. Nationalism \\
2. Honest & 11. loving country \\
3. Tolerant & 12. Appreciating the achievement \\
4. Discipline & 13. friendly/communicative \\
5. Work hard & 14. loving peace \\
6. Creative & 15. loving reading \\
7. Independent & 16. caring heart \\
8. Democratic & 17. caring about the environment \\
9. Curious & \\
\hline
\end{tabular}

Based on the formulation or elaboration of values developed in the culture and character of the national education, it can be seen its relevance to Sasak story "The Story of King Kuripan" values in literacy learning. Values in character education are included in the religious, ethical and social values contained in the Sasak story "The Story of King Kuripan".

Based on the formulation of values developed in the culture and character of the national education, it can be seen its relevance to the values of the Sasak story "The Story of King Kuripan" with learning literature. Values in character education are included in the religious, ethical, and social values contained in the Sasak story "The Story of King Kuripan".

Table 2

The Relevance of the Values of the Sasak Story "The Story of King Kuripan” with the Values of Character education

\begin{tabular}{cll}
\hline No & Values in Learning Literature & Values of Character Education \\
\hline 1 & Religious values & \\
1. Praise the Lord & 1. Religious \\
2. Stand on truth and justice & 2. Work hard \\
3. Surrender & 3. Independent \\
4. Thankful & 4. Nationalism \\
5. Pray & 5. Loving the country \\
Ethic Values & \\
1. Keep the promise & 1. Religious \\
2. Down to earth & 2. Discipline \\
3. loyal to the teacher & 3. Work hard \\
4. polite & 4. Independent \\
5. Wise & 5. curious \\
6. payback a favor & 6. loving reading \\
7. Responsible & \\
8. obedient to parents & \\
Social Values & \\
1. Helpful & 1 Creative \\
2. forgiving & 2. Independent \\
3. Togetherness and teamwork & 3. Democratic \\
4. loyal & 4. Friendly/communicative \\
5. Care about others & 5. Care about society \\
6. Loving and affecting & \\
7. Creating & \\
\hline
\end{tabular}

Herman, S., Wilian, S., \& Gunayasa, I. B. K. (2018). Structure and culture values of sasak story: story of king kuripan and its relevation with language and literature learning. International Journal of Linguistics, Literature and Culture, 4(6), 17-27. https://doi.org/10.21744/ijllc.v4n6.335 
8. enthusiast and diligent

9. Brave

Attitude values that can be taught in learning literature for junior high school students are as follows. a) Religious value. b) Praising the greatness of God c) Surrender d) Value of Education e) Cultural Value f) Value of mutual cooperation g) Value of attitude.

\section{Attitude Values}

a) Compliance Value, Obedience or Loyalty, this value is reflected in the various behaviors of the character in the Sasak story "The Story of King Kuripan" for example following all the instructions or the instructions in a wide-open manner without arguing.

b) Value of Honesty, the value of honesty is a value that must be maintained or preserved. This value is the basic character of everyone, including the Sasak story "The Story of King Kuripan” even though he made a mistake he was frank about the mistakes he made.

c) The values that must be avoided/shunned include: (1) carelessness, (2) acts of violence, (3) attitude to reflect/imitate without consideration and recognizing the situation, and (4) provide incomplete lessons

\section{Conclusion}

Based on the results of the study and the discussions that have been carried out, a number of conclusions can be drawn, including the following. The Sasak story "The Story of King Kuripan". is a story that is still in the form of oral literature, but the Sasak community still remembers the story of the king or datu bumi Sasak located in Kuripan village, West Lombok. The Sasak folklore "The Story of King Kuripan" led by Prabu Aria is known for his charismatic leadership character and attitude that is always wise full of patients in living a life both as a leader of the Sasak community and in the family.

All of these things can be seen in terms of the structure of the Sasak story "The Story of King Kuripan" including 1) Themes, themes in Sasak folklore "The Story of King Kuripan" led by Prabu Aria. 2) The flow, Sasak folklore in West Lombok Regency is generally forward or straight, the storyline from beginning to end is easy to understand. 3) The figure, Sasak folklore, West Lombok Regency, namely Kuripan King known as a wise and charismatic leader in leading both family and community.4) Background, the background of the Sasak folklore "The Story of King Kuripan" in West Lombok is more widely used (dominant). 5) Mandate, the mandate of Sasak Raja Kuripan folklore in West Lombok Regency in the story is quite varied.

The cultural value found in Sasak Raja Kuripan folklore in West Lombok Regency is the educational value contained in the Raja Kuripan folklore. The educational value of the Sasak folklore the Sasak story "The Story of King Kuripan". In West Lombok Regency includes the value of moral education, the value of traditional education (tradition), the value of religious education (religion), the value of heroic education (the spirit of struggle). 1) The value of moral education in the folklore "The Story of King Kuripan" is that people must have a strong heart, sincerity, and patience. It can be identified from the study that the Kuripan King led by Prabu Aria is a leader who is patient and wise. 2) The value of the traditional education of Sasak folklore "The Story of King Kuripan" is the wise treatment of a leader who is always known as the king or datu as a role model. 3) The value of religious or religious education, in Sasak folklore "The Story of King Kuripan" is led by Prabu Aria who is known for being a very obedient, patient and wise leader who is always known by the Sasak people. 4) The value of historical education, in the folklore, "The Story of King Kuripan" values of historical or historical education are the name of a datu or king is taken from the name of the kingdom of kahuripan in Java. 5) The heroic values of in Sasak folklore "Raja Kuripan" is the spirit of defending the homeland and caring for the condition of the community.

\section{Conflict of interest statement and funding sources}

The authors declared that they have no competing interest. The study was financed by personal funding. 
Statement of authorship

The authors have a responsibility for the conception and design of the study. The authors have approved the final article.

\section{Acknowledgments}

This research can be resolved with the aid of various parties in the form of guidance, necessary data, criticism and suggestion, and motivation gave incessantly. For my beloved parents, thank you for the guidance during the process of doing and writing this research. And thanks to all people who cannot be mentioned one by one, who have supported me during conducting this research.

Herman, S., Wilian, S., \& Gunayasa, I. B. K. (2018). Structure and culture values of sasak story: story of king kuripan and its relevation with language and literature learning. International Journal of Linguistics, Literature and Culture, 4(6), 17-27. https://doi.org/10.21744/ijllc.v4n6.335 


\section{References}

Abdullah, I. T., \& Teeuw, P. P. D. A. (1988). Hikayat Meukuta Alam:: Suntingan teks dan terjemahan beserta telaah struktur dan resepsinya (Doctoral dissertation, Universitas Gadjah Mada).

Bartlett, F. C. (1932). Remembering: An experimental and social study. Cambridge: Cambridge University.

Bettencourt, E., Konopka, J., \& Damania, A. B. (1989). Directory of germplasm collections. 1. I. Food legumes. IBPGR.

Brooks, P. (1992). Reading for the plot: Design and intention in narrative. Harvard University Press.

Burhan, N. (2002). Teori Pengkajian Fiksi.

De Saussure, F. (2011). Course in general linguistics. Columbia University Press.

Driver, R., \& Bell, B. (1986). Students' thinking and the learning of science: A constructivist view. School science review, 67(240), 443-56.

Faruk. (1999). Pengantar Sosiologi Sastra Yokyakarta; Pustaka Pejajar Offset

Goldmann, L. (1977). Lukács and Heidegger: Towards a new philosophy.

Hamzah, A. (1985). Ghalia Indonesia. Jakarta1990.

Ikram, A., \& Pudjiastuti, T. (1997). Filologia Nusantara. Pustaka Jaya.

Kleden-Probonegoro, N. (1998). Pengalihan wacana: lisan ke tulisan dan teks.

Moleong, J. (2011). Lexy, Metode Penelitian Kulalitatif, Bandung: Pt Remaja Rosdakarya, cet. View in ( Google Scholar).

Piaget, J., \& Marfà, J. (1995). Seis estudios de psicología (No. 159.922. 73). Labor,.

Preminger, A., Hardison, O. B., \& Kerrane, K. (1974). Classical and medieval literary criticism: translations and interpretations. Frederick Ungar.

Riffaterre, M. (1979). La production du texte (Vol. 25). Seuil.

Teeuw, A. (1984). Sastra dan ilmu sastra: Pengantar teori sastra (No. 7). Pustaka Jaya.

Teeuw, A. (1988). Sastra dan Ilmu Sastra, Teori Pengantar Sastra. Jakarta: Pustaka Jaya.

Teeuw, A. (1994). Indonesia: antara kelisananan dan keberaksaraan. Pustaka Jaya.

Vansina, J. M. (1985). Oral tradition as history. Univ of Wisconsin Press. 


\section{Biography of Authors}

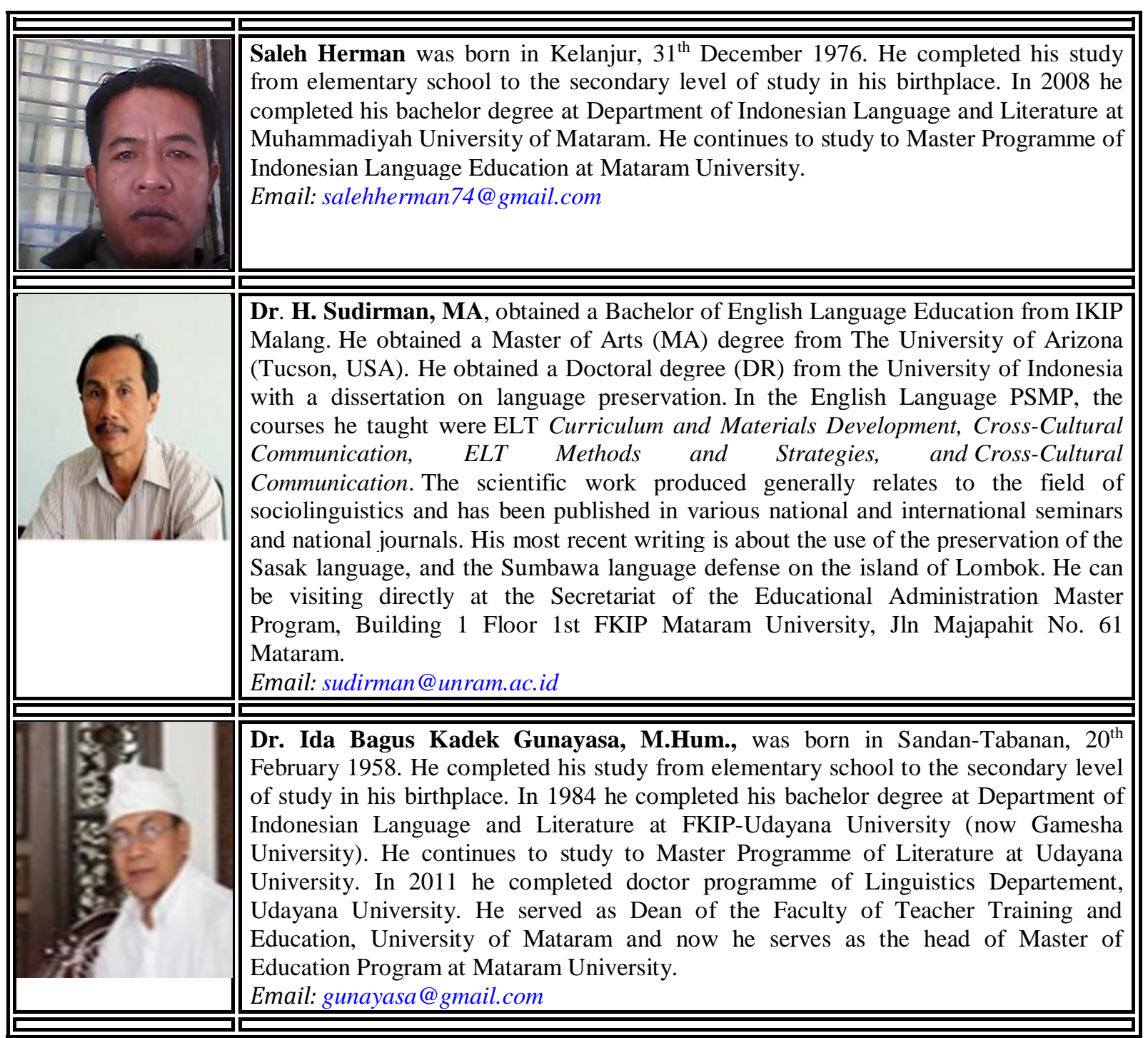

Herman, S., Wilian, S., \& Gunayasa, I. B. K. (2018). Structure and culture values of sasak story: story of king kuripan and its relevation with language and literature learning. International Journal of Linguistics, Literature and Culture, 4(6), 17-27. https://doi.org/10.21744/ijllc.v4n6.335 